\title{
The USA Pandemic (COVID-19) and Home-Based Electronic Instruction
}

\author{
Steven Gerardi \\ Department of Social Science, New York City College of Technology, CUNY, New York, USA \\ Email: Tutti50wag@aol.com
}

How to cite this paper: Gerardi, S. (2020) The USA Pandemic (COVID-19) and HomeBased Electronic Instruction. Sociology Mind, 10, 222-225.

https://doi.org/10.4236/sm.2020.104014

Received: September 7, 2020

Accepted: October 24, 2020

Published: October 27, 2020

Copyright ( 2020 by author(s) and Scientific Research Publishing Inc. This work is licensed under the Creative Commons Attribution International License (CC BY 4.0)

http://creativecommons.org/licenses/by/4.0/

\begin{abstract}
With the onset of COVID-19 pandemic in the USA many schools closed and were replaced with in-home computer instruction. This action, required Computers, Internet, and WIFI to access the daily lessons. This effort will suggest that many of the poor/working class parents of many of these students will be unable to afford the luxuries of Computers, Internet, and WIFI. Hence, these students/children will be unable to access the class sessions and assignments, negatively affecting their intellectual and social growth.
\end{abstract}

\section{Keywords}

Human Capital, Loss of Educational Achievements, 1929 USA "Economic Great Depression”, In Class Instruction, In Home Electronic Instruction, Loss of Intellectual Outcomes

\section{Introduction}

Human capital is the total knowledge, skills, experiences, and education which add to the individual's ability to create personal economic and social benefits. Indeed, in the USA human capital is an investment in both the individual and society. The individual invests in education creating a return of increased earnings, and better working conditions (Gerardi, 2010). Evidence has been amassing which suggests that quality education is critical for the sustained social and economic growth of nations, and individuals. Moreover, several studies have shown that the number of years of education is a strong determinant of occupational achievements (with social origins held constant (Sewell \& Shah, 1977 in Power and Ideology in Education, Karrabul and Halsy)).

Indeed, requirements of post-modern society's occupations are constantly increased and changing. Therefore: 1) the proportion of jobs requiring low skill 
has decreased; and 2) the proportion requiring higher order skills has increased. Hence, formal education has become increasingly important in today's post-modern economy. Therefore, a larger proportion of the population is required to spend longer and longer periods earning a formal education. Moreover, human capital accounts for a substantial portion of economic growth in society; indeed, human capital has grown at a much faster rate than conventional capital (Gerardi, 2010).

Additionally, human capital is a form of consumption for the individual and acts as a socially and economic investment. Indeed, from this perspective the individual can consider him/herself a capitalist in that the individual makes investments in the acquisition of knowledge and skill, hence the growth of economically valuable capacities (low earnings reflect according to this theory, inadequate investments in education).

According to Schultz, 1961 capital theory further suggests that investment in education nationally facilitates economic growth in two ways: spurring technological innovation and increasing the productivity of labor. Throughout the last several decades human capital theory has served as a guideline and justification for rising educational expenditures both by government and individuals alike (human capital theory also suggests that those who do not acquire the proper dose of schooling are likely to occupy the low positions of the socioeconomic hierarchy). Therefore, there is a significant correlation between the national income per capita, and the levels of education among the labor force.

\section{In-Home Electronic Instruction: Context of Study}

Technological advancements historically were originally viewed as a force which freed humanity from the toils of repetitive manual labor, hence liberating humanity (Gerardi, 2017). However, today's Pandemic (COVID-19) has closed in-class schooling instruction, and has regulated instruction to in-home computer-based instruction impacting the level of human capital invested in these children; in addition creating a new normal human identity-based conformity, simple thought, and loss of critical thinking (Gerardi, 2017).

Prof. Patricia Greenfield (2009) of UCLA in her work entitled "Is Technology Producing a decline in Critical Thinking and Analysis" suggested that technology (but also for the purposes of this effort in-home instruction) has negatively affected skills in critical thinking and analysis. This effort cites these data to suggest that argument that computer In-home based instruction will have had a profound negative effect on human intellectual outcomes.

Furthermore, exposure to the simplifying effects of in-home computer instruction may also have declining anatomical function on the brain, social and intellectual outcomes, and the possible human capital of these students. Moreover, there is a strong data correction which suggests that enrichment increases the size of the brain, and the learning curve. On the other hand, a lack of enrichment, this effort suggested will decrease the size of the brain negatively effecting the learning outcomes of the students. By contrast a brain not enriched 
may decrease the learning curve. This effort suggests that In-Home computer instruction will do the latter to the 2020 COVID-19 student body (Diamond, 1998).

\section{Conclusion}

This effort argued that in-home computer instruction will have a negative effect on children's learning, creativity, and critical thinking (defined as the ability to create concepts, read and interpret argument, employing inductive/deductive reasoning in solving problems, and keeping an open mind, inquisitiveness, flexibility, and the ability to develop individuality).

As we saw earlier, Diamond (1998) argued that the brain relies on the process of creating critical thinking through enrichment and by increasing the size of the brain. On the other hand, a lack of enrichment may decrease the size of the brain and lower the learning curve.

Hence, this effort strongly suggests that over exposure to the forces of in-home computer instruction will lead to 1) social conformity, 2) loss of individuality, 3) stunted social and intellectual development; and 4) lower critical thinking.

Finally, as was mentioned earlier in the abstract section, the children of the poor/working class will take the burden of these negative effects on intellectual growth, largely because the parents are unable to afford the luxury of computers, WIFI, and the internet long term affecting the socio-economic status of these students as adults.

There is growing evidence that whether the sociological perspective is the influence of family background on school and occupation achievement (status attainment approach), or the mode of production in material life (Marxist approach), or the language-use at home and at school (socio-linguistic approach), or cultural socialization (cultural reproduction), or the changing needs and requirements of society's educational demands (structural-functionalist approach), students from working class and low socio-economic backgrounds (SES), do poorly in school, compared to the middle class children. Additionally, in-home computer-based instruction will have a long-term negative intellectual effect (on the children of the above mention socio-economic backgrounds).

At first glance this educational policy concerning the in-class instruction seems independent of one another; however in the educational continuum of the individual the educational effect is cumulative in nature (such educational career paths lead to student biographies and identities which crystalize during the individuals' educational life cycle). This effort has argued that in-home computer-based instruction will become another factor to the student biography (Gerardi, 2010).

Lastly this effort further argued that many of the poor/working class parents will be unable to afford the luxuries of Computers, Internet, and WIFI. Hence, these children will be unable to access the class sessions and assignments, negatively affecting their educational outcomes and social growth. 
To sum up, during the USA "Great economic Depression of 1929" many primary school students were forced to leave school and go to work (as child labor) to help support the family. Indeed, the majority of these children as adults never recovered from the loss of their education (human capital). Likewise, the children of the 2020 COVID-19 pandemic, this effort further has argued, will unfortunately experience the same negative socio-economic outcome of the 1929 "Great Economic Depression” primary school students.

\section{Conflicts of Interest}

The author declares no conflicts of interest regarding the publication of this paper.

\section{References}

Diamond, M. C. (1998). Magic Trees of the Mind: How to Nurture Your Child's Intelligence, Creativity, and Healthy Emotions from Birth through Adolescence. New York: Plume, Penguin Group.

Gerardi, S. (2010). A Brief Survey of the Sociological Imagination (3rd ed.). Kendall and Hunt.

Gerardi, S. (2017). Use of Computers/Apps and the Negative Effect on Children's Education. Sociology Mind, 7, 128-132.

Greenfield, P. (2009). Is Technology Producing a Decline in Critical Thinking and Analysis. Science Daily. https://www.sciencedaily.com/releases/2009/01/090128092341.htm

Schultz (1961) 2004 Human Capital. American Review, 5.

Sewell, \& Shah (1977). Power and Ideology in Education, by Karrabul and Halsy. 